\title{
Ishayahu Landa*
}

\section{Türaqai Güregen (d. 1296-7) and His Lineage: History of a Cross-Asia Journey}

https://doi.org/10.1515/asia-2017-0011

\begin{abstract}
The history of the Mongol conquests in Eurasia was not least the history of the numerous migrations of masses of people across the continent. This essay discusses one specific case study, namely that of the Mongol commander and Chinggisid imperial son-in-law Türaqai of the Oyirad tribe and his lineage throughout the thirteenth century. He himself was probably born in Iran or Iraq. His family, however, came from Mongolia to Iran during the Mongol conquests. The article discusses Türaqai's life, in particular his (and his army's) flight from the Ilkhanate to the Mamlūk Sultanate in 1296. He also made an unsuccessful attempt to become part of the Mamlūk military, which costed him and his close supporters their lives. Looking through the lenses of this biographical narrative, the essay presents a broader picture of the military nomadic migrations in Chinggisid Eurasia and their mechanisms. The essay also pays special attention to the position of the Chinggisid sons-in-law, who held a highly respected status in the Mongol political architecture. Additionally, it highlights some main issues related to the migration of the nomadic tribes and their resettlement in the newly conquered areas under the Mongol rule, such as assimilation, conversion to Islam and the different dimensions of their relations with the local populations.
\end{abstract}

Keywords: Ilkhanate, Mamlūk Sultanate, Mongol army, islamisation, imperial Sons-in-law, migration, mobility, tribal armies

Shortly before January 1296, Türaqai Güregen, the Ilkhanid son-in-law of Oyirad origin, accompanied by about a tümen of his tribesmen, their families and livestock, crossed the Euphrates and asked for asylum in the Mamlūk Sultanate. ${ }^{1}$ Ever since the defeat of the Mongols by the Mamlūk Sultan Kuṭu

1 Bar Hebraeus/Budge 1976: 508 (cf. al-Maqrīzī 1934: 812). "Güregen” is an indication of the son-in-law in the Chinggisid political context - that of the imperial son-in-law of the Golden lineage (see Landa 2016b: 161-164 for a discussion of the concept of the güregens and their position in the Mongol political architecture).

*Corresponding author: Ishayahu Landa, Department of Asian Studies, The Hebrew University of Jerusalem, Har Ha-Tsofim, Jerusalem 91905, Israel. E-mail: ishayahu.landa@mail.huji.ac.il 
(r. 1259-1260) on September 4, 1260, the relations between the Ilkhanate and the Mamlūk Sultanate had been tense and former migrants had made their way from the Ilkhanate. ${ }^{2}$ Never before, however, and never again had the Sultanate experienced such a large-scale migration of Mongols. So who was the leader of these Mongols and why is his biography important for our understanding of Mongol Eurasia? This essay will attempt to answer these questions.

Türaqai was born in the mid-thirteenth century most probably either in Iraq or Iran. His family, however, originated from the steppes of the Mongolian plateau and belonged to the Oyirads, one of the most powerful Mongolian tribes. In the early thirteenth century, this tribe was located in the steppe-forest border zone between today's south-eastern Siberia and northern Mongolia and became one of the main and early supporters of the Chinggisids. ${ }^{3}$ Shortly after its peaceful submission by Chinggis Khan, the tribe rose to the status of güregens (imperial sons-in-law) of the Chinggisids through the establishment of matrimonial relations. This symbolised the elevated status of the Oyirad tribal nobility as part of the extended blood clan of the Mongol ruling family, ${ }^{4}$ whereas the tribe itself became part of the Abode of Peace (il) under the Mongol rule. ${ }^{5}$

Türaqai Güregen belonged to the top tier of the Oyirad nobility and Mongol elite. He was a descendant of Qutuqa Beqi, the Oyirad leader of Chinggis Khan's era, in the fourth generation. Around 1207, Qutuqa Beqi had been rewarded by the Khan for his readiness to submit and had been granted the right to marry two of his sons - Inalchi and Törelchi - to the women of the Golden urugh (lineage), and his daughter, Quluy Ikachi, to Chinggis Khan's son, Jochi. ${ }^{6}$ Törelchi, the great-grandfather of Türaqai, married Checheyigen, one of the five daughters of Chinggis Khan and his chief wife Börte Füjin. This strengthened the position of the Oyirad tribe in comparison to most of the other Steppe tribes. ${ }^{7}$ Of Törelchi’s three known sons, Buqa Temür, Bars Buqa and Börto’a, at

2 On Mongol-Mamlūk relations during the 1250s to 1290s, see Amitai 1987; Amitai-Preiss 1990; Amitai-Preiss 1995. On Mongol migrations to the Sultanate, see Ayalon 1951; Satō 1997: 99-103, Nobutaka 2006; Amitai 2008.

3 For a detailed discussion of the Oyirad tribe, its early history and relations with the Chinggisids, see Broadbridge 2016; Landa 2016a, 2016b: 80-85.

4 Cf. Rykin 2013, esp. 250-254 and passim.

5 For the concept of $i l$ (peace, submission) versus bulgha (revolt), see Doerfer 1965: 194-201: 194-201; Fletcher 1986: 19-20. Unlike other large Mongol tribes, the Oyirads are not explicitly known to have participated in the campaigns of Chinggis Khan. See the later Mongol chronicle, Altan Tobchi, according to which, due to the permission of Chinggis Khan himself, the Oyirads remained in their dwelling areas (Danzan/Shastina 1973: 112-114).

6 De Ratchewiltz 2006 (hereafter SH), 1: 164: Rashīd al-Dīn 1999 (hereafter JT), 1: 55; cf. Bai Cuiqin 2008: 27-29, Landa 2016b: 178.

7 JT, 1: 55, cf.; Landa 2016b: 178, fn. 85. 
least two can be clearly identified as güregens. ${ }^{8}$ Unlike his two brothers who were active in Mongolia and China, Türaqai's grandfather, Buqa Temür, migrated westward, taking part in the Western campaign of Hülegü Khan (r. 1256-1265). ${ }^{9}$ Since then his descendants' history became disconnected from that of the Mongol politics of the Great Khan in Dadu (大都, Beijing) and the events in Mongolia.

It is unclear whether Türaqai's grandfather was also a güregen. ${ }^{10}$ Still, his status seems to have been rather special during the campaign. Buqa Temür participated in it mainly as a representative of his mother Checheyigen, Hülegü's aunt, ${ }^{11}$ commanding a significant amount of Oyirad troops and closely advising Hülegü. ${ }^{12}$ In autumn 1256, Buqa Temür participated in the war against the Isma ${ }^{2} l_{i s}{ }^{13}$ and was among the few commanders who insisted on continuing the siege of Maymūn Diz, the Isma îlis' main stronghold, ${ }^{14}$ which eventually turned out successful. Later on, as a tümen ${ }^{15}$ commander, he played an important role in the Mongol conquest of Baghdad in 1258 and the following subjugation of Arabic Iraq. Thus, a few days after the beginning of the siege, on January 22, Buqa Temür, along with other important commanders, is recorded to have gained control of the western side of Baghdad. ${ }^{16}$

8 Bars Buqa married an unnamed daughter of Tolui Khan (JT, 2: 461; Bai Cuiqin 2008: 31), and Börtö'a yet another woman from the Golden urugh, whom Bai Cuiqin identifies as Princess Yixiji 一悉基 of unclear origin (Bai Cuiqin 2008: 30-31; Ao et al. 1983: 32; cf. JT, 1: 56, fn. 5).

9 Both Börtö'a and Bars Buqa remained in Mongolia and possibly participated in the Mongol campaigns in China. The lineage of Börtö'a remained closely connected with Qubilai Khan, serving him at least until the death of Börtö'a's sons (JT, 1: 56; Bai Cuiqin 2006: 8, 2008: 30-31). Bars Buqa's lineage was also recorded by Rashīd al-Dīn as serving Qubilai, but, at least some of his descendants actively supported Arigh Böke and possibly Qaidu, thus alienating themselves from the ruling clan of the Yuan dynasty (Landa 2016b: 187-188).

10 No sources I have read mention him as such, but Hammer-Purgstall, one of the most influential German orientalists of the nineteenth century, called him a "Stiefschwager" (inlaw) of Hülegü (Von Hammer-Purgstall 1842: 86). Unfortunately, I was not able to identify the sources he used.

11 Juvayni//Boyle 1997: 607-608. It was a normal practice to dispatch a representative of one Chinggisid lineage to the realms of others. Cf. JT, 2: 487; see Jackson 1978: 216-218.

12 (JT, 2: 496. Cf. also Shu'ab-i Panjgāne (Qiu Yihao 2013, hereafter SP): 188; Mu'izz al-ansāb 2006 (hereafter MA): 75.

13 JT, 2: 483.

14 JT, 2: 484.

15 I.e. amīr-i tūmān, commander of ten thousands of warriors. For the general definition of tümen, see Doerfer 1965: 632-642 and; Darley-Doran 2000: 619, for the rank in the Ilkhanid military, see Calmard 1989.

16 JT, 2: 495, cf. Boyle 1961: 156-157. 
After February 1, Buqa Temür and his tümen were ordered to patrol the water routes from Baghdad towards Madā'in and Bașra in order to prevent the enemy soldiers from escaping. This operation was successful, the troops of Buqa Temür forcing Mujāhid al-Dīn Aybeg, the lesser dawātdār ("vice-keeper of the inkwell") of the Caliph, to return to the besieged city. ${ }^{17}$ About a week after these events, Buqa Temür was sent by the Khan "to test the people of Hilla, Kūfa and Wāsiț”, following the request of the people of Hilla to appoint them a governor. This expedition led to the establishment of Mongol administration in Wāsiț, Shūshtar and Bașra. ${ }^{18}$

In addition to all these military successes (and probably partly due to them), Türaqai Güregen's lineage ${ }^{19}$ is known to have been tightly connected to the Golden urugh in the Ilkhanate and beyond, continuing the tradition established during the first half of the thirteenth century (see Figure 1). ${ }^{20}$ Türaqai's father, Buqa Temur's son Jaqir, was married to a daughter of Hülegü Khan, his own cousin. ${ }^{21}$ This was only one of his family's complex marital connections with the Chinggisids. ${ }^{22}$ The complexity of the matrimonial relations between the Hülegüids and Buqa Temür's lineage attest to its high position at the Ilkhanid court. The matrimonial relations also hint at a significant amount of military power which the clan could offer the Hülegüids and which thus secured the clan's position as one of their main allies. ${ }^{23}$

17 JT, 2: 496.

18 JT, 2: 499-500.

19 For the sake of this paper I prefer to distinguish between the three different Oyirad lineages (see below), and not clans, as I did earlier (Landa 2016a). This formulation seems to be more precise for the current discussion, as it concentrates on the Oyirad commanders' patrilineal families of two or three generation only and not on their extended clans (cf., at the same time, the mentioning of the Qonggirad clan of Dei Sechen below, p. 14, fn. 74). This oversimplifying of a complex scientific discussion (cf. Khazanov 1994: 122) is needed to provide a unifying basis for the following limited discussion, but does not in any case means the author's ignoring of the broader research context.

20 Note that the genealogical charts in this paper include only those of the Chinggisids, who were intermarried with the specific Oyirad lineages under discussion.

21 JT, 1: 56-57; MA: 78.

22 At least six sisters of Buqa Temür (another report claims some of them to be his daughters) married into the ruling Chinggisid houses across the Steppe, mostly still during the United Empire. Furthermore, many of Hülegü's children with Oyirad background (mainly those born from his two official Oyirad wives, Güyüg and Öljeitü Khatuns, sisters of Buqa Temür and Türaqai's grand-aunts) were married to Oyirads, probably for strengthening the union of the two clans (JT, 2: 473-476; Landa 2016a: 151-154).

23 See JT, 1: 55-56; Wașșāf/Hammer-Purgstall 2010: 29-30; JT, 2: 473-476 for the details on the relations of the members of Türaqai's lineage with the Golden urugh. 


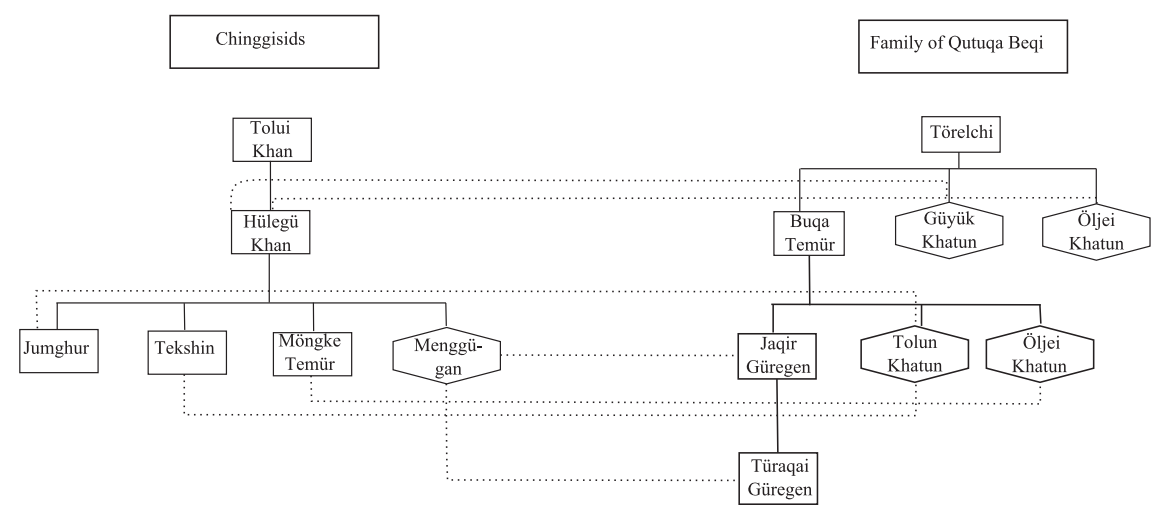

$\left[\begin{array}{ll}\hline \text { son/daughter of } & \square \text { male } \\ \cdots \cdots \text { matrimonial connection } & \square^{\text {female }}\end{array}\right.$

Figure 1: Matrimonial connections between Qutuqa Beki's lineage and the Chinggisids.

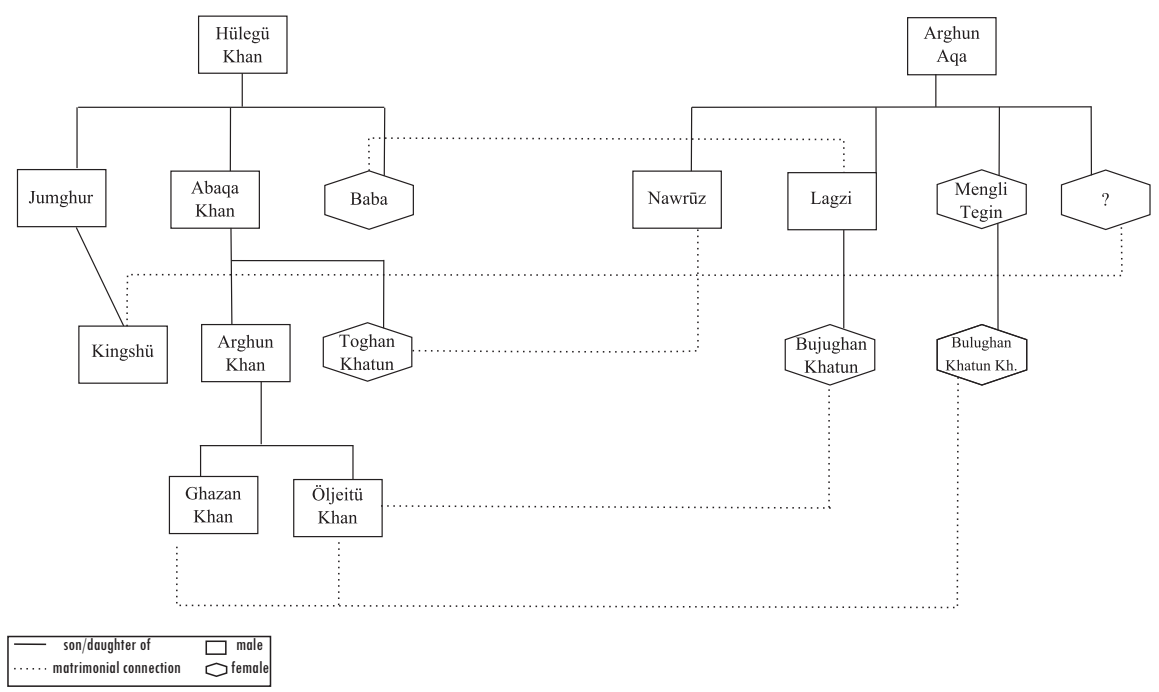

Figure 2: Matrimonial connections between Arghun Aqa's lineage and the Chinggisids.

Buqa Temür passed away around $1260 .^{24}$ Following his death his lineage disappeared from the Ilkhanid political scene until the events of January 1296, with which this essay has begun. As I argued elsewhere, the reasons for this disappearance from the sources may lie in the Jochid connections of Buqa Temür, and

24 JT, 2: 503. 
especially his relations with the two Jochid Khans, Möngke Temür (r. 1266-1280) and Töde Möngke (r. 1280-1287), both sons of his sister Köchü Khatun. ${ }^{25}$ Yet we are not aware of any Oyirad troops or commanders of importance stationed in the Jochid territories. The Oyirad presence in the Jochid ulus was apparently limited to the Oyirad representatives at the Jochid court, possibly related to Köchü Khatun. The very fact, however, that one of the most important Ilkhanid commanders, almost a member of the ruling clan, was so tightly interconnected to the two successors to the Jochid throne might have become a trigger for the removal of Buqa Temür's lineage from the Ilkhanid power circles, which had already begun since the late 1250's. ${ }^{26}$

Be that as it may, Buqa Temür's lineage, represented at that time both by Jaqir, his son, and Türaqai, his grandson, was removed from the court during the decades following Hülegü's demise. ${ }^{27}$ Before the 1290 s they resided between

25 JT, 2: 352. See more in Landa 2016a: 153, fn. 10; Landa 2016b: 180-181. Note that Broadbridge (2016) seems to not consider the death of Buqa Temür a relevant factor in the discussion of the Oyirad power constellations at the Ilkhanid court in its early decades, in fact not mentioning it at all. It seems to me, however, that one cannot analyse the Oyirad presence in the Ilkhanate without discussing the demise of Buqa Temür's clan in the broader historical context. This, of course, in any case does not diminish the importance of other misfortunes which weakened the status of the lineage at the Ilkhanid court, such as the sudden deaths of Jumghur (JT, 2: 519) and Möngke Temür (JT, 2: 545) (for a broader discussion of these issues see Broadbridge 2016: 127128, cf. pp. 134-135).

26 Another interesting fact is the rise of Arghun Aqa's lineage at more or less the same time, namely around 1260. Indeed, while Buqa Temür was connected with Hülegü, Arghun Aqa was closely connected to Abaqa, Hülegü's son and successor (r. 1265-1282), probably since the young Abaqa had been stationed in Khurasan (see JT, 3: 516-517, cf. Jackson 1986: 402). Arghun Aqa was of unclear Oyirad origin, but certainly not of the elite lineage of Qutuqa Beqi (cf. Juvaynī/Boyle 1997: 505 and JT, 1: 57). Note that in the list of Abaqa's commanders, Arghun Aqa is listed first place, while in that of Hülegü, he appears in the middle (SP: 190-191, 242; MA: 82). Those relations were further strengthened by the marriage of Nawrūz, Arghun Aqa's son and Ghazan Khan's famous commander, to Abaqa's fourth daughter Toghan Khatun (JT, 3: 517). One can suppose that after Buqa Temür's death, the steady deterioration of the Ilkhanid-Jochid relations under Hülegü or, more probably, Abaqa, initiated the expulsion of Buqa Temür's lineage from power (for more on the Jochid-Ilkhanid relations during the first two decades of the Ilkhanid rule, see Boyle 1968: 352-359; Vásáry 2009: 76-78). Possibly Arghun Aqa and his lineage played a role in this process. In fact, Lagzi, son of Arghun Aqa, lost his positions as an amir of the Cherkess during Abaqa's reign (SP: 247, cf. MA: 83). Perhaps this was due to his connection to Buqa Temür's lineage through his marriage to Baba Khatun, the daughter of Hülegü from Öljei Khatun, sister of Buqa Temür, (JT, 2: 476, and cf. Figure 2).

27 Note Broadbridge 2016: 128, fn. 43 and 132, fn. 66, who claims that Jaqir and Türaqai participated in the Syrian campaign (1281) of Möngke Temür, the half-Oyirad son of Hülegü, their Hülegüid nephew and cousin respectively. I was not able to figure out the factual basis of this claim (cf. Amitai-Preiss 1995: 195, esp. fn. 63 and Bar Hebraeus/Budge 1976: 464 on the 
Diyarbakr and northern al-Jazira. ${ }^{28}$ It is possible that after 1260 these Oyirads troops had already been located in that area. ${ }^{29}$ The amount of Oyirad tribesmen in those territories under the control of Buqa Temür's lineage apparently was very significant. ${ }^{30}$ It was probably this military strength as well as the position of Jaqir as the imperial son-in-law which still guaranteed the lineage a certain status after the death of Türaqai's grandfather. After Jaqir's death, Türaqai married his stepmother Menggügen, probably in order to preserve the status of his lineage as well as his personal position vis-à-vis the court in Tabriz. ${ }^{31}$ It is not completely clear whether Türaqai was given another princess after his wife's demise. ${ }^{32}$ If not, this would attest to the degradation of his position towards the end of the thirteenth century.

Oyirad armies during the Battle of Homs without mentioning any names of the Oyirad commanders).

28 Baybars al- Manșūī 1998: 309, cf. Bar Hebraeus/Budge 1976: 597-598.

29 Smith does not specifically mention Oyirads in his discussion of the Ilkhanid tümens' dwelling areas, but indicates Diyarbakir as an important qishlaq (winter pasture) (Smith 1999: 46-47, esp. fn. 30). Cf., however, Bar Hebraeus/Budge 1976: 597-598, who claims that they were wintering close to Mosul, i.e. about $500 \mathrm{~km}$. from Diyarbakr.

30 The amount of Oyirad troops which came to the Sultanate is estimated by the Arabic authors between 10,000 and 18,000 warriors and/or about 10,000 families. See more on these calculations in Landa 2016a: 159, fn. 32.

31 JT, 1: 57. The levirate marriages, in which a man marries a sister or a relative of this wife after her death, were very typical for the Mongols. Cf. Ratchnevsky 1968; Serruys 1957: 171-190; Holmgren 1986 and Birge 1995. Note that this remarriage of Türaqai on his father's Hülegüid wife is not mentioned by Broadbridge 2016 in the text of the article and does not also appear in the relevant table in her paper (idem: 129, Table 3).

32 According to many sources he indeed got Ara Qutlugh, a daughter of Möngke Temür, son of Hülegü Khan from Öljei Khatun, his great aunt (e.g. JT, 1: 57; MA: 83; Baybars al-Manșūrī 1998: 309). On the other hand, Rashīd al-Dīn contradicts himself in another place where he says she was given to Türaqai Güregen but mentions that after Türaqai's death, Ara Qutlugh was given to Doladai Idachi, another important commander (JT, 2: 475). As I have already suggested elsewhere, this second Türaqai Güregen, the husband of Ara Qutlugh, could have been Türaqai Güregen of the Qonggirad, son of Qutlugh Temür Güregen, another important “in-law” lineage of the Ilkhanate (Landa 2016a: 158, fn. 31, see the same point in Landa 2016b: 181, fn. 100; cf. a short note on this Qonggirad güregen in JT, 3: 515). Note that Broadbridge mentions in her paper that Türaqai married Ara Qutlugh, daughter of Möngke Temür, son of Hülegü, and cites JT, 2: 475 without any critical consideration (idem: 128-129). As the text in JT, 2: 475 explicitly mentions that Türaqai Güregen, the husband of Ara Qutlugh, died and the princess was remarried, it is highly improbable that the real husband of Ara Qutlugh was indeed Türaqai of the Oyirads. Also note that both my relevant footnotes in Landa 2016a, 2016b are a bit misleading, not contradicting, though, my major claim, as they do not mention the crucial remark in JT, 2: 475, but cite JT, 3: 515 only. Note also the typo in; Landa 2016b: 181, fn. 100, which claims that according to the later $M u^{\prime} i z z$ al-Ansāb Türaqai married Ara Qutlugh before 
Türaqai was included in the list of the commanders of Hülegü and Abaqa. ${ }^{33}$ However, he vanishes from the Persian sources very quickly so that it is mainly Arabic sources which tell us the following events of Türaqai's life. What interests them, however, are mainly the events which happened after Türaqai's immigration to the Sultanate, thus the information concerning the events in the Ilkhanate is very limited. The Mamlūk sources inform us that the real reason for Türaqai's defection was his participation on the side of Ilkhan Baidu (r. 1295) in the killing of Ilkhan Geykhatu (r. 1291-1295). ${ }^{34}$ After Baidu's defeat by Ghazan and the rise of Ghazan to the Ilkhanid throne during the autumn of 1295, all the old supporters of Baidu, including Türaqai, faced an imminent death threat. ${ }^{35}$ Indeed the Mamlūk sources claim that shortly before his escape, a special unit was sent by Ghazan to capture Türaqai. ${ }^{36}$ The threat was, thus, a personal one, concerning Türaqai himself and, possibly, the closest members of his family. However, Türaqai left the Ilkhanate not alone, but with a huge army, as well as his and his soldiers' families and livestock. The decision to escape to the Mamlūk Sultanate seems to have been motivated partly by the fact that the Sultanate had already given asylum to a number of Mongols during the previous decades. Moreover, it was located relatively close to Diyarbakr, the dwelling areas of Türaqai. Of greatest importance, however, was the Oyirad origin of the reigning Mamlūk sultan al-Malik al-`Ādil Zayn al-Dīn Kitbughā al-Manșūrī (r. 1294-1296) who had risen to the throne in Cairo after a coup d'état against Sultan al-Nāșir Muhammad b. Qalāwūn (r. 1292-1294, 1299-1309, 1309-1341), just a few months before the Oyirad migration. ${ }^{37}$ Possibly the Sultan's Oyirad origin encouraged Türaqai to flee towards Syria, not towards Caucasus, another more dangerous option, since it would also have led him too close to Tabriz.

The sources emphasized the origin of Sultan Kitbughā and did not hesitate to mention that his support of the Oyirads was based on their common ethnic origin (jins). ${ }^{38}$ The Mamlūk Sultan, indeed, reacted positively

Menggügen, as it should be "after" (cf. correct version in Landa 2016a: 158: fn. 31). The confusion might have happened due to the close proximity of the two amirs' names. This issue needs a further research.

33 SP: 190, 250; MA: 75, 83.

34 Al-'Aynī 1989: 304; al-Manșūrī 1998: 309.

35 Cf. JT, 3: 628.

36 Al-Maqrīzī 1998: 309.

37 The new Sultan originally came to the Sultanate as a captive, but entered the Mamlūk Manșūriyya unit and rose to power under Sultan al-Manșūr Sayf al-Dīn Qalāwūn (r. 1279-1290). On him and his history, see, e.g., Ibn Kathīr 1993, 13: 399; Ibn Taghrïbirdī 1986, 7: 55; Ibn alDawādāri 1971: 361; cf.; Amitai 2008: 122, fn. 16.

38 Ibn al-Dawādārī 1971: 361. 
to the Oyirad arrival. He immediately settled the main body of the tribesmen on the coastal area of Northern Palestine, near 'Atlit. ${ }^{39}$ Their leaders, however, were to be escorted to Egypt to meet the Sultan. In the following days a special group, consisting of four important Mamlūk commanders, left Egypt to meet the Oyirad leaders in al-Shām. ${ }^{40}$ First, the Oyirad commanders and elders were granted access to Damascus, which they entered on January 30 1296. ${ }^{41}$ They were met there with great enthusiasm and stationed in Ablaq Castle. ${ }^{42}$ On February 12 they started their way to Cairo. ${ }^{43}$ Their arrival was celebrated in great pomp by the Sultan in Qal'at al-Jabal, his headquarters. ${ }^{44}$ The honours granted by Sultan Kitbughā to the newcomers were numerous: they entered the military ranks of the Mamlūk army and were granted salaries and iqta $\bar{a} t$. $^{45}$ Thus, Türaqai was appointed țablkhāna (commander of forty) ${ }^{46}$ and Ūlūs, his supporter, commander of ten. ${ }^{47}$ Apparently, Kitbughā wanted to go as far as to grant Türaqai the rank of commander of hundred and to give him a thousand warriors. ${ }^{48}$ This would have ranked Türaqai among the highest amirs of the Sultanate. ${ }^{49}$

Understandably, Kitbughā's enthusiasm and his generous support of the newcomers did not find support among the Mamlūk elite. Their main complaint was that the Oyirads were not Muslims. In fact, they remained shamanist throughout the decades that they spent in the Ilkhanate. The Mamlūk amirs argued that it would be more suitable to first convert the newcomers, become assured of their Islamic faith and, and only then to grant them access to the army and other

39 Baybars al-Manșūrī 1998: 310; al-Nuwayrī 1923: 299; Ibn al-Dawādārī 1971: 362.

40 Zetterstéen 1919: 39; Al-Nuwayrī 1923: 298; Al-Maqrīzī 1934: 812; Ibn al-Furāt 1939: 204; Ibn al- Dawādāri 1971: 362; Ibn Taghrībirdī 1986, 7: 60; Baybars al-Manșūrī 1998: 310.

41 Al-Nuwayrī 1923: 298; Al-Maqrīzī 1934: 812.

42 Zetterstéen 1919: 39; Ibn al-Dawādārī 1971: 362; Baybars al-Manșūūī 1998: 310.

43 Zetterstéen 1919: 39; Al-Maqrīzī 1934: 812; Ibn al-Furāt 1939: 204. The amount of the Oyirad elders and commanders differ between 100 and 300 (Zetterstéen 1919: 39; Al-Nuwayrī 1923: 298; Al-Maqrīzī 1934: 812 and cf.; Ibn Abī al-Faḍāil 1919: 590 and; al-Maqrīzī 1998: 43).

44 Ibn al-Furāt 1939: 20.

45 On the iqta' a $\bar{t}$ (Islamic type of tax farms) in general, see Cahen 1971; on the iqta ${ }^{\circ} \bar{t} t$ in the first decades of the Mamlūk Sultanate in Egypt and Syria, see Satō 1997: chs. 4, 5 and 8.

46 Ayalon 1953: 469-470.

47 Ayalon 1953: 470. See Al-Nuwayrī 1923: 298; Al-Maqrīzī 1934: 812; Ibn al-Furāt 1939: 204; Ibn al-Dawādārī 1971: 362; Ibn Taghrībirdī 1986, 7: 60; al-'Aynī 1989: 305-306; Baybars alManșūī 1998: 310; Al-Maqrīzī 1998: 43; cf. Nobutaka 2006: 64-68 and Amitai 2008: 130-131 for the discussion of these appointments.

48 I.e. raising him to amïr mi'a wa muqaddam alf, the highest rank of the Mamlūk hierarchy (cf.; Ayalon 1953: 467-469).

49 al-'Aynī 1989: 306. 
corresponding privileges. ${ }^{50}$ Indeed, Islam was the main threshold for the entrance to the Mamlūk military society and one of its main uniting characteristics, so that such high honours for non-Islamic members were seen as a crime against the system. ${ }^{51}$ Furthermore, the newcomers themselves behaved in a rather scandalous way, which probably mirrored their confidence in their status in the Sultanate and in the Sultan's support. They sat (or were seated) on the places of the respected commanders during the feasts and meetings in the Citadel $^{52}$ and continued to openly practice their non-Muslim habits and customs. ${ }^{53}$

Despite all the pressure on the Sultan, Türaqai and his people remained privileged. Apparently, Kitbughā suggested to Türaqai to embrace Islam, but Türaqai refused. ${ }^{54}$ Still, the Sultan rejected the option of a forceful conversion of the Oyirads. ${ }^{55}$ The issue remained unsolved until November 1296, when Kitbughā was dismissed by the future Sultan Ḥisām al-Dīn Lājīn al-Manșūrī. ${ }^{56}$ Shortly after his rise to power, the new Sultan decisively dealt with the Oyirad nobility. Fearing that with the significant amount of warriors under their control they might bring the dismissed Sultan back to power, ${ }^{57}$ Lājīn incarcerated the Oyirad commanders in the Alexandria prison, where most of them were

50 Baybars al-Manșūīi 1998: 310; al-'Aynī 1989: 305, 308; Ibn Abi al-Faḍail 1919: 590-591.

51 See e.g. Ayalon 1975; Ayalon 1976, esp. 205-209 for a general discussion of the Mamlūk military.

52 Ibn Abi al-Fadail 1919: 590-591.

53 Two illustrious examples are given in the chronicles. Firstly, they slaughtered the horses for food in a way different from the manner accepted in the Islamic world. Secondly, and even more crucially, they ate openly during Ramadan, and raised the anger not only of the Mamlūk amirs, but also of the population of Cairo: “ ... and people loathed them ... and hated them, [and it went so far] that they demanded the dismissal of the Sultan [ ... ]," - reports the chronicler ( ... ). See AlNuwayrī 1923: 298; cf. Ibn al-Furāt 1939: 204 and Al-Maqrīzī 1934: 812; al-'Aynī 1989: 308.

54 Al-'Aynī 1989: 307-308.

55 Al-Maqrīzī 1998: 43.

56 It would be wrong to claim, however, that it was only the Oyirad issue which lead to the coup d'état. Kitbughā's support of the Oyirads and their disrespected and provocative behaviour, however, certainly played a role in shaking the position of the Sultan which had been unstable from the beginning (see Baybars al-Manșūrī 1998: 310; al-'Aynī 1989: 308, 311-312; AlMaqrīzī 1998: 44; but cf. Ibn Abi al-Faḍail 1919: 591-592; al-'Aynī 1989: 299-303 for the other reasons).

57 Those fears were not completely groundless, as in 1299, already under the new Sultan Ibn alQalawūn, the Oyirad troops made an unsuccessful attempt to bring Kitbughā back to power. One of the main leaders of the revolt was Ūlūs, the only known Oyirad commander from the inner circle of Türaqai who had been released from prison. This time all the leaders of the revolt were either hung or imprisoned (see Ibn al-Dawādāri 1960: 10; Baybars al-Manșūrī 1998: 330; Zetterstéen 1919: 58, cf. Amitai 2007: 227; Nobutaka 2006: 80.). 
executed. Among those whose life ended there was also Türaqai. We do not know how he died, but his body was buried in the cemetery of Alexandria. ${ }^{58}$

We do not possess any information about the descendants of Türaqai Güregen. Even if they existed, the historians decided not to include any details about them in either Egypt and Syria or the Ilkhanate. In the Ilkhanate, understandably, Türaqai became a traitor, and hardly no memory of him or his people has been preserved. Still, the sources record a significant presence of Oyirads in the Diyarbakr areas until at least the second half of the fourteenth century, and one wonders whether those Oyirads were originally ruled by Buqa Temür's lineage. ${ }^{59}$ In the Mamlūk Sultanate some rather lengthy reports about the Oyirads' fate were produced during the fourteenth - early fifteenth century due to the continuous presence of the Oyirad tribesmen in the Mamlūk Sultanate. Indeed, the Oyirads remained visible in Mamlūk society until the early fifteenth century, most clearly in Cairo, despite the fact that they converted rather quickly to Islam, entered the Mamlūk military en masse and intermarried with the Mamlūks, and possibly with the other inhabitants of the Sultanate. ${ }^{60}$ After the early fifteenth century, however, they disappear even from the Mamlūk sources, probably assimilating into the Turcoman nomadic tribes of Southern Syria and Northern Palestine, thus losing their Oyirad identity. ${ }^{61}$

\section{Analysis and conclusion}

The life-story of Türaqai Güregen and his lineage's history demonstrate some important features of the Mongol tribal elites. Firstly, Türaqai's lineage attests to the high position of the Chinggisids' sons-in-law in the Mongol political architecture. This position was very often transmitted hereditarily from father to son throughout generations, partly through the implementation of levirate or sororate marriages, quite typical for the nomadic cultures. A high degree of autonomy characterised those "in-law" clans and lineages, who possessed both administrative and military authority in their respective areas. The main source

58 Al-'Aynī 1989: 356, cf. al-Maqrīzī 1998: 43.

59 For the relevant sources and an in-depth discussion, see Landa 2016a: 167, fn. 74 and 175, fn. 121.

60 Cf. al-Nuwayrī 1923: 268. Their fate in the Sultanate, the distinctively Islamic environment, is an interesting issue which has been dealt with in another article (for a detailed discussion of the Oyirad presence in the Mamlūk Sultanate, both in the Cairo quarter al-Husayniyya and in the al-Shām, see Landa 2016a: 178-181).

61 Landa 2016a: 186-187. 
of power of the in-laws was the military under their command, augmented by their administrative posts and their kinship to the rulers. ${ }^{62}$

The importance of the in-laws in the analysis of the tribal nobility's relations with the Chinggisids has been in large ignored until recently. The most radical example is the claim of Hope, which completely separates the Chinggisids from their tribal aristocracy, ignoring the importance of the tribal in-laws in the Chinggisid political architecture (a somewhat surprising claim in the face of the available sources). ${ }^{63}$ The reason why Hope does not see the güregens as a primary operational and functional part is that he considers them "cadet members, or clients, of the extended royal family", 64 and ignores their military importance. Hope's statement that the "status of the küregen should not be over-stated", as "the offspring of such unions were never considered for political leadership, nor were they treated with the respect of full Chinggisid princes", 65 is misleading. Firstly, the analytical scope of Hope's research is limited to the Ilkhanate, and does not take into consideration the other Khanates, especially the Yuan and the princely status the güregens held there. ${ }^{66}$ Secondly, he ignores an important function of the güregens, namely that they provided empresses for the Chinggisid houses, in many cases the mothers of the future rulers. ${ }^{67}$ Thirdly, the very existence of the matrimonial relations between the tribal nobility and the Chinggisids already provided a major link between the two bodies, uniting them in one extended power continuum. Therefore, one should divide not between the tribal nobility (Hope: aristocracy) and the Golden urugh, but between the extended Chinggisid clans and the güregens vs. the other representatives of the tribal nobility.

Secondly, Türaqai's case exemplifies the phenomenon of the military desertion due to internal political struggles of the Mongol states. Mongol commanders and units often defected or fled after having supported the losing side in a political conflict and even senior elite members such as the in-laws were not immune to this fate. ${ }^{68}$ Seen in a broader perspective, however, these desertions are only one expression of the high amount and multi-faceted mobility that

62 Landa 2016b: 69-70.

63 See Hope 2016 in general and esp. his conclusion, where he crystallises his claim of a clash between the patrimonial vs. the collegial in the Ilkhanid political system (idem: 201-204).

64 Hope 2016: 40.

65 Hope 2016: 40.

66 Cf. Landa 2016b: 168-169.

67 To remain in the Ilkhanid space, one can point of Chichak Güregen, father of Hajji Khatun, mother of Abu Sa'īd (cf.; Landa 2016a: 164-165).

68 See, for example, the discussion between Nobutaka (2006) and Amitai (2008) for the highlighting of this phenomenon. 
characterised the political and social order of Mongol Eurasia. ${ }^{69}$ In addition, in Turaqai's case it was the whole military unit, at the same time the private tribal army of a specific lineage which deserted. Remarkably, this tribal army not only remained loyal to its Oyirad commanders after the dissolution of the United Empire and the establishment of the Ilkhanate, but also retained its nomadic character, dwelling patterns and shamanistic rituals.

Thirdly, Türaqai's case seems to be of special importance for a much larger theoretical issue, namely the question of the Mongol tribes' identities in the Mongol-ruled Islamic world and the interrelations of old and newly-acquired identity aspects. While I have already discussed some of these aspects elsewhere, ${ }^{70}$ it is worth to address this issue briefly here as well, thereby locating Türaqai's biography in its broader context, and pointing out three major facets of identity-building: the tribal, military and Islamic identities of the Mongol armies. What concerns the "tribal" identity, its complexity and fluidity should be kept in mind..$^{71}$ The rise of Chinggis Khan's super-tribal formation in the early thirteenth century led, on the one hand, to the breaking of multiple tribal structures, ${ }^{72}$ and, on the other, to the formation of a number of tribal armies, which retained their military and ethnic composition. ${ }^{73}$ Of crucial importance is the often-ignored fact that it was the affiliation to a specific lineage, which

69 This side of the Mongol rule in Eurasia included, beyond the obvious migration of people, also the very intensive cross-continental migration of ideas, commodities and deseases (see, e. g., Allsen 1987; 1997; 2004; Biran 2008; 2015; DeWeese 2006; Isahaya 2013; Kadoi 2009; Kauz 2006; Landa 2016b; Qiu 2016; Yang 2014 to name just a few, and note also the very interesting recent dissertation of Chen Chunxiao 2016 on the "migration" of the Chinese cultural elements into the Ilkhanate).

70 See Landa 2016a: 175-176, 183-187.

71 On the discussion of the notion of the "tribe" and the different approaches to its identity see Lindner 1982; Marx 1977; Khazanov 1994: xxxvi for the additional researcher and Fletcher 1986, esp. 16-19. For the discussion of Sneath vs. Golden, Barfield and Khazanov on whether the "tribe" as a basic category ever existed in the nomadic world or is a rather reinvented one and related to the aristocratical lineages only see Sneath 2007; Barfield 2009; Golden 2009; Khazanov 2010; cf. Wing 2016: 30.

72 Cf. Biran 2007: 41-43. One can suppose that in the result of the subsequent breaking of the tribal borders the affiliation to a specific military unit has become more important than the original tribal identity. Note also that a significant number of the tribes and clans mentioned by Rashīd al-Din in his "tribal" chapter" never reappear in the later sources or even in his own later chapters, possibly indicating the slow process of the disappearance of those identities. This issue belongs, in any case, to a separate research.

73 Those were exclusively those tribes, which surrendered peacefully (Qonggirads and Oyirads are the most explicit examples, but one can also turn to the Önggüd and the Uyghur examples). On this see, for example, Landa 2016b on the Oyirad and the Qonggirad tribal armies and their dispersion in Eurasia. 
cooperated with the Golden urugh, that held the tribal army together. In the Oyirad case, the clan of Qutuqa Beki represented the whole tribe, while possible others never appeared in the sources. ${ }^{74}$

Following the expansion of the Chinggisid conquests and the dispersion of the Chinggisid ruling families and their armies across Eurasia, the tribal units under Chinggisid control started to split up into smaller clans. With time, they established relationships with different Chinggisid lineages, often through matrimonial relations. ${ }^{75}$ This process led to the crystallisation of imperial in-laws' lineages, based on the specific lineage's identity, rather than that of a whole tribe. Based on the Oyirad example, this paper suggested the importance of such a perspective for the analysis of the tribal units and their connections with the Chinggisid houses. ${ }^{76}$ In this regard, one also has to rethink the importance of the ethnic solidarity ('așabiyya) - much discussed in previous research - in the context of the Ilkhanid history. ${ }^{77}$ It seems possible that the 'așabiyya did influence both Türaqai's decision to migrate to the Mamlūk realm and his relations with Kitbughā. ${ }^{78}$ Very different, however, were the conditions in the Ilkhanate, as the Oyirads around Ghazan, represented by the lineage of Arghun Aqa, not only did not support Türaqai and his lineage, but possibly played a role

74 To exemplify this case one can also turn to the Qonggirad history, where the extended clan of Dei Sechen appeared to have substituted the whole Qonggirad tribe with the time, while other lineages and clans, often hostile to Chinggis Khan, were annihilated (cf. JT, 1: 78). It might also be reasonable to remind the division of the Mongolian tribes on the eve of Chinggis Khan's rise suggested by Togan, who differentiated between the more structured, hierarchic tribes (such as the Naiman) and less hierarchic, opened to the rule by different lineages (such as the Qonggirads) (see Togan 1998: 10-11). It seems, therefore, that after Chinggis Khan's rise many of those "less differentiated" tribes have turned to the opposite extreme, where one nobility lineage represented the tribe, or at least was shown as such in the sources.

75 The analysis of this process is the primary theme of my dissertation in preparation.

76 This was shown in this paper on the example of the two separate lineages: those of Buqa Temür, Arghun Aqa, but we can see it everywhere (cf. the Qonggirad clan of Elchi Noyan vs. others, less known, originating from his uncle Daritai's family, on this issue see Landa 2016b: 165-166 and; Landa forthcoming [a] on the Sufi-Qonggirad lineage of Kharazm under the Jochids). Note also the third Oyirad lineage in the Ilkhanate, that of Tengiz Güregen. It rose to power after the demise of Arghun Aqa's lineage and its number of matrimonial connections with the Hülegüids was, arguably, the biggest one. Since it is beyond the scope of this paper, the relevant chart is also not included here. See the detailed discussion in Landa 2016a, esp. 164-174.

77 Cf. Lapidus 1990: 28 and passim.

78 But the other factors should also not be ignored: the examples of many of the other Mongols traitors and refugees, as well as the geographical proximity of Diyarbakir to Syria. Note also the way the Mamlūk amirs judged the relations between the Oyirad newcomers and the Sultan (Landa 2016a: 161-163). 
in removing him from the power circles. ${ }^{79}$ It seems, therefore, that the 'așabiyya cannot serve as an ultimate analytical tool for understanding the tribal politics under Mongol rule, and a more nuanced, lineage-oriented approach is needed. ${ }^{80}$ In any case, the decisive element behind the question whether the ethnic solidarity played any important role or not seems to be the existence of broader affiliation structures, which could substitute or "reformulate" tribal bondages (in our case - the Chinggisid lineages). It is therefore very interesting that following the collapse or weakening of the Chinggisids, we witness the process of the so-called "retribalisation" processes, i.e. a renewed turn to the "original" tribal identity as a major affiliation marker, in many cases across Eurasia. ${ }^{81}$

79 There are no direct indications on this, but this remains an option (see also below).

80 The otherwise very important recent paper of Broadbridge (2016), which deals with the Oyirad intermarriages in the Ilkhanate, unfortunately avoids the division between the different Oyirad lineages (this can be seen in the tables provided in the paper, cf. Broadbridge 2016: 125, Table 2 and 129, Table 3). The importance of the division, much discussed in this paper, is stressed further by the fact that one does not see intermarriages (with one exception) between the different Oyirad lineages in the Ilkhanate (cf. Landa 2016a: 153, fn. 9; cf.; Broadbridge 2016: 125-128). This only exception is Lagzi, son of Arghun Aqa, who married Baba, daughter of Öljei Khatun, wife of Hülegü, and sister of Buqa Temür (JT, 2: 471). They had a daughter, Bujughan Khatun, who later became one of Sultan Öljeitü's Oyirad wives (Landa 2016a: 164, fn. 61), but did not marry any other Chinggisid with Oyirad roots. It is possible that this marriage between Lagzi and Baba did not take place for ethnic reasons, but that the decision was influenced by pragmatic considerations of the court, due to the importance of Arghun Aqa to the Hülegüids. Note also that of the three daughters of Hülegü and the Elder Öljei Khatun (Jamai, Menggügen and Baba), only Menggügen was married with an Oyirad (Jaqir), while Jamai was given to Joma Güregen of the Tatars (JT, 2: 476). Additionally, note the distinctive specific geographic connection of the different Oyirad clans (Diyarbakir for Buqa Temür's lineage and Khurasan for that of Arghun Aqa), see more Landa 2016a: 154-155, 167-168, esp. fn. 74; and note some indications that 'Alī Pādshāh, the famous great-grandson of Tengiz Güregen, had also some connections to Diyarbakir [Landa 2016a: 167, fn. 74]).

81 Cf. Togan 1998: 13. On the Jalayir case in the post-Ilkhanid space cf. also the position of Wing, who disconnects the Jalayirid rise of the mid-fourteenth century from the general retribalisation processes, owning this more to the personal capacities of Shaykh Hassan Buzurg and the support of parts of the Oyirad troops granted to him (Wing 2016: 94, 196; on these events see also Landa 2016a: 171-172). At the same time, note the importance Wing grants to the fact of Shaykh Hassan's grandfather, Aq Buqa and Amir Husayn, his son, becoming güregens through their marriage with Arghun's daughter Üljatay Sultan (Wing 2016: 65-66). Not entering a lengthy discussion of the Jalayirid revival, which I do see as a part of the broader retribalization phenomenon and which belongs to a different research, it would be just suffice to stress here, that the identity marker chosen by the Jalayirids was, in fact, their own tribal affiliation, not the one of their Oyirad supporters and any other. In fact, one should not see the retribalisation as the return to the past. To remind, the Jalayirids were not allowed to intermarry with the Golden urugh according to the jasaq, as they were originally seen as the bö'ol (hereditary slaves) of Chinggis Khan (Xie Yongmei 2012: 206-208). At the same time, multiple 
In addition to the importance of the lineage as an affiliation marker of the Mongol tribal armies, the case of Türaqai also stresses the importance of a military unit for the identity formation. Following both the logic of the conquests and the logic of the occupational forces' imposing of power it seems possible to claim that the military identity of the Mongol troops was fused with the tribal ones in many cases. This holds true in particular from the geographical point of view (i.e. the division of the occupied territories among the military units and their livestock). ${ }^{82}$ Thus the identification with the specific tribal lineage seems to have often taken place primarily in the context of this lineages' control imposed on a specific tribal army. Therefore, for the matter of the discussion, it seems that the "Oyirad" identity of Türaqai's army in Diyarbakir was different from the "Oyirad" identity of Nawrūz and his people, or, later, of 'Ali Padshāh's Oyirad units, as their primary affiliation identity marker, the nobility lineage in charge, was different. ${ }^{83}$ As this discussion is beyond the limits of this paper, it should only be mentioned that in some cases the new tribal identities developping in the Ilkhanid and the Chaghadaid areas seem (especially since the mid-fourteenth century) to have originally had not some tribal basis, but had its roots in a specific military unit (cf. the Apardi, Ja'uni Qurban, Hizaras and Qaraunas). ${ }^{84}$

Jalayirid lineages all across Mongol Eurasia have established matrimonial connections with the Chinggisid houses starting with the second half of the thirteenth century, thus making a break with the original rule. The explanation of this fact would demand a broader discussion of the specific cases in each and every Khanate, and it would be sufficing to claim that this breakage with this jasaq rule had a lot to do with the practical need of the Chinggisid lineages for the power and military support after the collapse of the United Empire. Returning to the Jalayirid case in the Ilkhanate, it seems quite suitable to talk about the "retribalisation" at the moment, when the tribal identity again becomes a formidable one in the construction of a state, an ethnic entity or a tribal army. The case of the Jalayirids, therefore, does not differ significantly from the other ones.

82 Cf. Smith 1999 for the discussion of the territorial tümen division in the Ilkhanate.

83 It is also important to mention that we do not have any information on Nawrūz, the very important military commander of the two last decades of the thirteenth century, having under his control explicitly Oyirad troops. Differently, Türaqai and 'Ali Padshah were clearly in the control of the Oyirad armies (see the discussion above and Landa 2016a: 167, fn. 74 and 170-171. To remind, Nawrūz's father was originally not a military person, and family had seemingly much more to do with the local population, than with their own tribesmen (on this see Landa forthcoming [b]).

84 On the Hizaras see Bacon 1951; on the Apardi and Qara'unas see Manz 1989: 154-155, 159161; for the research of the Ja'uni Qurban see Smith 1970: 94; Paul 2011; and cf. Landa forthcoming [b]). On the similar discussion and its extension up to the formation of the Ottoman identity see Jackson 2017: 401-405. 
In other cases it was possibly the identity of the commander which defined the identity of the whole group. ${ }^{85}$

Complementary to this set of different "tribal" and military identities of the Mongol armies in Western Asia appears the "Islamic" one, which became more and more relevant for broader groups of the Mongol military since the end of the thirteenth century. ${ }^{86}$ While the importance of the islamisation for the tribal assimilation in a longer run is undeniable, it seems that the Islamic identity of the Mongol troops did not strongly interpolate or come into conflict with the tribal identities in the first decades of the Mongol troops' presence in Western Asia. Surely, we are aware of multiple conflicts between the "Islamic" and "nonIslamic" groups among the Chinggisids and the Mongol military in the different Khanates, but those were not "tribal-Islamic" conflicts proper, but "shamanisticIslamic", or those of the "jasaq vs. sharī'a" kind. ${ }^{87}$ At the same time, the broader Islamic identity never led to the disappearance of the tribal ones, and, as mentioned above, we witness a wave of "retribalisation" processes toward the mid-fourteenth century all across Mongol Eurasia. The tribes reinvented their "tribal" identity after or following the collapse or significant weakening of the Chinggisid authorities across the continent. ${ }^{88}$

To return to Türaqai's case, as was shown, the group around him remained shamanistic until the very end of the thirteenth century. I have already discussed the processes of the Oyirad relations with the overwhelmingly Arabic and

85 Again, the Jalayirid case can be useful, but also the "Oyirad armies" of the post-Ilkhanid space seem to have been formed around this principle at least up to some degree. In some sense, this is an extension of the identity principle mentioned above, according to which the tribal military unit formed his identity according to the tribal lineage in charge, but a different one from the case of Türaqai's army, where we surely know it to be the "Oyirad" one ethnically (see the discussion on the ethnic features of the Oyirad males and females, provided by the Mamluk authors, in Landa 2016a: 175, fn. 159 and 187-189). Also note, that in some cases it could be the name of the commander only that had the identity-giving function (cf. Jackson 2017: 402-403).

86 The study of the Mongol islamisation has become one of the most discussed in the three decades in the field. The research either concentrated on the royal conversions (Melville 1990; Vásáry 1990; DeWeese 1994; Amitai-Press 1996; Pfeiffer 1999; Amitai 2001; Biran 2002, 2016), or on the conversion of the Mongol military (Pfeiffer 2006; De Nicola 2016; as well as Landa forthcoming [b]). Cf. a broader discussion in Jackson 2017: 329-332 on the issue of the conversion to Islam.

87 On the conflicts between jasaq and shari'a, especially in the issues of ritual purity, food and marriage customs, see, for example, Elverskog 2010: 227-240; Jackson 2017: 306-307, cf. Amitai-Preiss 1996: 4-5, 10.

88 Note, also, that by that time Islam proper was hardly the only identity of the Muslims, multiple ethnic, geographical and political ones being intertwined together. Cf. also Jackson 2017: 402. 
Islamic Mamluk Sultanate and the difference between their assimilation in the Mamluk Sultanate and the Ilkhanate elsewhere. ${ }^{89}$ As I have suggested, the major conflict between Buqa Temür's lineage and the Ilkhanid authorities started at the time of Buqa Temür's death, long before the Ilkhanid conversion to Islam, ${ }^{90}$ and while it is possible that Türaqai's support of Baidu was a religious or antiIslamic choice (vs. the increasing support of Ghazan from the already Islamised parts of the Mongol military including Türaqai's "tribesman” Nawrūz), there is no information to confirm this. Most probably, the primary reason for Nawrūz not helping Türaqai in the latter's conflict with Ghazan was political, and not religious, as they both belonged to different political parties. ${ }^{91}$

One more point should be stressed, namely that the discussion of the Mongol Islamisation and the consequent "assimilation" into the Muslim environment should not obligatory presume that the application of the new Islamic identity automatically brought to an end all previous ones. While this would suit the exclusive claim of Islam as a universalistic religion, this was certainly not the reality. In the end, while De Nicola has recently discussed a "multi-vectored" Islamisation, referring to the existence of multiple channels of conversion, why should we not talk about the "multi-faceted" identity of the tribal armies after their conversion? ${ }^{92}$ That the Oyirad identity disappeared both in the Mamluk Sultanate and the Ilkhanid space towards the early fifteenth century had probably less to do with Islam per se, but more with the relatively small number of Oyirads if compared with the host societies, their intermarriage with the local populations, the diffusion of the tribal units and the dying out of their nobility. ${ }^{93}$

Originating in Southern Siberia, the Oyirads were dispersed throughout Eurasia by the Mongol Empire in a rather short period of time. Their status as imperial sons-in-law, the top rank of the non-Chinggisid hereditary nobility at the Chinggisid courts, facilitated this process, forcing the sons-in-law and their clans to move with the patrons all across Eurasia. Tens of thousands of their

89 Landa 2016a: 183-187.

90 Landa 2016a: 153, fn. 10.

91 In fact, there are no sources which in any form suggest those two ever spoke one with another. Though this is, of course, possible, the lack of any information on the communication between the two different Oyirad lineages, related both to the same Chinggisid clan, most probably indicate a strong enmity between the two. It is also important to remember that the origin of Arghun Aqa, Nawrūz's father, was not a noble one, and he never claimed any relation to the broader lineage of Qutuqa Beki. At the same time, if Türaqai's support of Baidu had indeed any anti-Islamic features (which cannot be confirmed), the juxtaposition of Nawrūz and Türaqai becomes more religiously motivated enmity.

92 De Nicola 2016: 364-365, cf. Jackson 2017: 332.

93 Cf. Landa 2016ba: 183-187. 
tribesmen followed them, bringing along their respective families, possessions and livestock. The significance of these migration waves, one of the main outcomes of the Mongol conquests, as well as their long-lasting influence on the cultural, ethnic political and economic characteristics of the host societies, but also those of the host societies on them throughout Eurasia is still to be fully understood. Reconstructing the biographies of such people as Türaqai Güregen and his lineage, however, helps to shed light on this process, gaining insights into the fate of Mongol migrants at a crossroad of cultures, religions and ethnicities under the largest continental Empire in human history.

Funding: The research leading to these results has received funding from the European Research Council under the European Union's Seventh Framework Programme (FP/2007-2013)/ERC Grant Agreement 312397.

\section{Bibliography}

al-'Aynī, Badr al-Dīn Maḥmūd b. Aḥmad (1989): 'lqd al-jumān fí ta'rīkh ahl al-zamān. Cairo: AlHai'a al-Mișrīyya al-'Āmma li al-Kitāb.

Allsen, Thomas T. (1987): Mongol Imperialism: The Policies of the Grand Qan Möngke in China, Russia, and the Islam. Lands 1251-1259. Berkeley, CA: University of California.

Allsen, Thomas T. (1997): Commodity and Exchange in the Mongol Empire. Cambridge: Cambridge University Press.

Allsen, Thomas T. (2004): Culture and Conquest in Mongol Eurasia. Cambridge: Cambridge University Press.

Al-Maqrīzī, Ahmad b. 'Ali (1998): Al-Mawā'iẓ wa al-i'tibār fí dhikr al-khiṭaț wa-al-āthār, Vol. 3. Beirut: Dār al-Kutub al-`Ilmiyya.

Al-Maqrīzī, Aḥmad b. 'Alī (1934): Kitāb al-sulūk li-ma'rifat duwal al-mulūk, Vol. 1. Edited by M.M. Ziada. Cairo: Lajnat al-ta'līf wa al-tarjama wa al-nashr.

Al-Nuwayrī, Shihāb al-Dīn Aḥmad b. 'Abd al-Wahhāb (1923): Nihāyat al-arab fi funūn al-adab. Cairo: Dār al-Kutub al-Mișriya.

Amitai, Reuven (1987): “Mongol Raids into Palestine (A.D. 1260 and 1300)”. Journal of the Royal Asiatic Society of Great Britain and Ireland 2: 236-255.

Amitai, Reuven (2001): “The Conversion of Tegüder Ilkhan to Islam". Jerusalem Studies in Arabic and Islam 25: 15-25.

Amitai, Reuven (2007): "Whither the Ilkhanid Army? Ghazan's First Campaign into Syria (1299-1300)”. In: Warfare in Inner Asian History (500-1800). Edited by N. Di Cosmo. Leiden: Brill, 221-264.

Amitai, Reuven (2008): “Mamluks of Mongol Origin and their Role in Early Mamluk Political Life”. Mamlūk Studies Review 12.1: 119-138.

Amitai-Preiss, Reuven (1990): "In the aftermath of 'Ayn Jālūt: The Beginnings of the MamlūkIlkhānid Cold War”. Al-Masāq 3: 1-21. 
Amitai-Preiss, Reuven (1995): Mongols and Mamluks: The Mamluk-llkhanid War, 1260-1281.

Cambridge: Cambridge University Press.

Amitai-Preiss, Reuven (1996): “Ghazan, Islam and Mongol Tradition: A View from the Mamlūk

Sultanate". Bulletin of the School of Oriental and African Studies 59.1: 1-10.

Anonymous (2006): Mu'izz al-ansāb [MA]. Edited by Sh. Kh. Vohidov. Almaaty: Dayk-Press.

Ao, Namonandaoerjiruo, Sizhen, Hu, Enhebatu, (1983): “Guanyu Mengge Khan shibei he gongdian de faxian 關於蒙哥汗石碑和宮殿的發現 (Regarding the Discovery of the Stone

Stele and Palace of Möngke Khan)". Xibei minzu daxue xuebao 3: 23-26.

Ayalon, David (1951): “The Wafidiyya in the Mamluk Kingdom”. Studia Islamica 25: 89-10.

Ayalon, David (1953): "Studies on the Structure of the Mamluk Army-Il". Bulletin of the School of Oriental and African Studies 15.3: 448-476.

Ayalon, David (1975): “Preliminary Remarks on the Mamluk Military Institution in Islam”. In: War, Technology, and Society in the Middle East. Edited by V.J. Parry and M.E. Yapp. London and New York: Oxford University Press, 44-58.

Ayalon, David (1976): “Aspects of the Mamlūk Phenomenon”. Der Islam 53: 196-225.

Bacon, Elizabeth (1951): "The Inquiry into the History of the Hazara Mongols of Afghanistan". Southwestern Journal of Anthropology 7.3: 230-247.

Bai Cuiqin (2006): Wala shi 瓦刺史. Guilin: Guangxi shifan daxue chuban shi.

Bai Cuiqin (2008): “Woyila guizu yu Chenjisihanxi lianyin kaoshu 斡亦刺貴族與成吉思汗系聯姻 考述”. In: Xi menggu shi yanjiu 西蒙古史研究. Edited by Du Rongkun and Bai Cuiqin. Guilin: Guangxi shifan daxue, 24-46.

Bar Hebraeus (1976): The Chronography of Gregory Abu'l-Faraj: 1225-1286. Translated and commented by A.W. Budge. Amsterdam: APA-Philo Press.

Barfield, Thomas (2009): "Review of the book The Headless State: Aristocratic Orders, Kinship Society, and the Misrepresentation of Nomadic Inner Asia by David Sneath". Comparative Study in Society and History 51.4: 942-943.

Baybars al-Manșūrī (1998): Zubdat al-fikrah fĩ tārīkh al-hijra. Berlin: Das Arabische Buch.

Biran, Michal (2002): "The Chaghadaids and Islam: The Conversion of Tarmashirin Khan (133134)". Journal of the American Oriental Society 122.4: 742-752.

Biran, Michal (2007): Chinggis Khan. Oxford: One World Publications.

Biran, Michal (2008): “Chaghadaid Diplomacy and Chancellery Practices: Some Preliminary Remarks". Oriente Moderno 88.2: 369-392.

Biran, Michal (2015): “Encounters Among Enemies: Preliminary Remarks on Captives in Mongol Eurasia”. Archivum Eurasiae Medii Aevi 21: 27-42.

Biran, Michal (2016): “The Islamization of Hülegü: Imaginary Conversion in the Ilkhanate". Journal of Royal Asiatic Society Third Series 26.1-2: 79-88.

Birge, Bettina (1995): "Levirate Marriage and the Revival of Widow Chastity in Yüan China”. Asia Major 8.2: 107-146.

Boyle, John A. (1961): “The Death of the Last 'Abbāsid Caliph: A Contemporary Muslim Account”. Journal of Semitic Studies 6: 145-161.

Boyle, John A. (1968): "Dynastic and Poitical History of the İl-Khāns". In: The Cambridge History of Iran. Vol. 5: The Saljuq and Mongol Periods. Edited by J. A. Boyle. Cambridge: Cambridge University Press, 303-421.

Broadbridge, Anne F. (2016): "Marriage, Family and Politics: The Ilkhanid-Oirat Connection". Journal of Royal Asiatic Society Third Series 26.1-2: 121-135.

Cahen, Claude (1971): "Iqțā". $E I^{2}$ 3: 1088-1091.

Calmard, J. (1989): “Amīr(-e) Tūmān”. Elr 1: 971. 
Chen Chunxiao (2016): Yilihanguo de zhongguo wenming - yi yimin, shizhe he wuzhi jiaoliu wei zhongxin,伊利汗国的中国文明-一以移民、使者和物质交流为中心. Unpublished PhD dissertation, Peking University.

Danzan, Lubsan (1973): Altan Tobchi (“Zolotoe Skazanie”, “Golden Summary”). Translated by N. P. Shastina. Moscow: Nauka.

Darley-Doran, R.E. (2000): “Tūmān”. El 10: 619-621.

De Nicola, Bruno (2016): "The Role of the Domestic Sphere in the Islamisation of the Mongols". In: Islamisation: Comparative Perspectives from History. Edited by Andrew C.S. Peacock. Edinburgh: Edinburgh University Press, 353-376.

De Ratchewiltz, Igor (2006): The Secret History of the Mongols: A Mongolian Epic Chronicle of the Thirteenth Century, Vols. 1-2. [SH]. Leiden: Brill.

DeWeese, Devin (1994): Islamization and Native Religion in the Golden Horde: Baba Tükles and Conversion to Islam in Historical and Epic Tradition. University Park: Pennsylvania State University Press.

DeWeese, Devin (2006): “Cultural Transmission and Exchange in the Mongol Empire: Notes from the Biographical Dictionary of Ibn al-Fuwațī”. In: Beyond the Legacy of Genghis Khan. Edited by Linda Komaroff. Leiden: Brill, 11-29.

Doerfer, Gerhard (1965): Türkische und mongolische Elemente im Neupersischen: unter besonderer Berücksichtigung älterer neupersischer Geschichtsquellen, vor allem der Mongolen- und Timuridenzeit, Vol. 2. Wiesbaden: Steiner.

Elverskog, Johan (2010): Buddhism and Islam on the Silk Road. Philadelphia: University of Pennsylvania Press.

Fletcher, Joseph (1986): “The Mongols: Ecological and Social Perspectives”. Harvard Journal of Asiatic Studies 46: 11-50.

Golden, Peter (2009): "Review of the book The Headless State: Aristocratic Orders, Kinship Society, and Misrepresentations of Nomadic Inner Asia by David Sneath". The Journal of Asian Studies 68.1: 293-296.

Holmgren, Jennifer (1986): "Observation on Marriage and Inheritance Practices in Early Mongol and Yüan Society, with Particular Reference to the Levirate". Journal of Asian History 2: 127-192.

Hope, Michael (2016): Power, Politics, and Tradition in the Mongol Empire and the Ikhanate of Iran. New York: Oxford University Press.

Ibn Abi al-Faḍail, al-Mufaddal (1919): Histoire des sultans mamlouks, Vol. 2. Edited by E. Blochet. Paris: Firmin-Didot.

Ibn al-Dawādārī, Abū Bakr b. 'Abd Allāh (1960): Kanz al-durar wa-jāmi' al-ghurar, Vol. 9. Edited by Hans R. Roemer. Cairo: al-Ma'had al-Almānī li’l-Ātār.

Ibn al-Dawādārī, Abū Bakr b. 'Abd Allāh (1971): Kanz al-durar wa-jāmi' al-ghurar, Vol. 8. Edited by Ulrich Haarmann. Cairo: al-Ma'had al-Almānī li'l-Ātāār.

Ibn al-Furāt, Muḥammad b. 'Abd al-Raḥīm (1939): Tārīkh Ibn al-Furāt, Vol. 8. Edited by Costi K. Zurayk and Nejla Izzedin. Beirut: American University Press.

Ibn Kathīr, Abū al-Fidā' Ismā'īl b. 'Umar (1993): Al-Bidāya wa al-nihāya fĩ al-tārīkh, Vol. 13. Beirut: Dar Ihyaa al-Turath al-'Arabi.

Ibn Taghrībirdī, Abū al-Maḥāsin Yūsuf (1986): Al-Nujūm al-zāhira fĩ mulūk Miṣr wa al-Qāhira, Vol. 7. Cairo: Matba’at Dār al-Kutub al-Misriyya.

Isahaya, Yoichi (2013): "The Tārīkh-i Qitā in the Zỉj-i Îlkhānī: the Chinese Calendar in Persian”. SCIAMVS: Sources and Commentaries in Exact Sciences 14: 149-258.

Jackson, Peter (1978): “The Dissolution of the Mongol Empire”. Central Asiatic Journal 22: 186-244. 
Jackson, Peter (1986): “Arḡūn Āqā”. Elr 2: 401-402.

Jackson, Peter (2017): The Mongols and the Islamic World: From Conquest to Conversion. Yale: Yale University Press.

Juwaynī, 'Ala al-Dīn 'Atā Malik (1997): Genghis Khan: The History of the World Conqueror. Translated and commented by J.A. Boyle. Manchester: Manchester University Press.

Kadoi, Yuka (2009): Islamic Chinoiserie: The Art of Mongol Iran. Edinburgh: Edinburgh University Press.

Kauz, Ralph (2006): “The Maritime Trade of Kish during the Mongol Period”. In: Beyond the Legacy of Genghis Khan. Edited by Linda Komaroff. Leiden: Brill, 51-67.

Khazanov, Anatoly M. (1994): Nomads and the Outside World. Madison: The University of Wisconsin Press.

Khazanov, Anatoly M. (2010): "Review of David Sneath, The Headless State: Aristocratic Orders, Kinship Society, and the Misrepresentation of Nomadic Inner Asia”. Social Evolution \& History 9.2: 206-208.

Landa, Ishayahu (2016a): "Oyirads in the Ilkhanate and the Mamluk Sultanate in the Thirteenth to the Early Fifteenth Centuries: Two Cases of Assimilation into the Muslim Environment”. Mamlūk Studies Review 19: 149-191.

Landa, Ishayahu (2016b): "Imperial Sons-in-law on the Move: Oyirad and Qonggirad Dispersion in Mongol Eurasia”. Archivum Eurasiae Medii Aevi 22: 161-197.

Landa, Ishayahu (forthcoming [a]): "From Mongolia to Khwarazm: The Qonggirad Migrations in the Jochid Ulus (13c.-15c.)”. Revue des mondes musulmans et de la Méditerranée: 143.

Landa, Ishayahu (forthcoming [b]): "New Light on Early Mongol Islamisation: The Case of Arghun Aqa's Family”. Journal of Royal Asiatic Society, Third Series.

Lapidus, Ira (1990): "Tribes and State Formation in Islamic History”. In: Tribes and State Formation in the Middle East. Edited by Philip S. Khoury and Joseph Kostiner. Berkeley: University of California Press, 25-47.

Lindner, Rudi P. (1982): “What Was a Nomadic Tribe". Comparative Studies in Society and History 24.4: 689-711.

Manz, Beatrice F. (1989): The Rise and Rule of Tamerlan. Cambridge: Cambridge University Press.

Marx, Emmanuel (1977): "The Tribe as a Unit of Subsistence: Nomadic Pastoralism in the Middle East”. American Anthropologist 79.2: 343-363.

Melville, Charles (1990): "Pādshāh-i Islām: The Conversion of Sultan Maḥmūd Ghāzān Khān”. Pembroke Papers 1: 159-177.

Nobutaka, Nakamachi (2006): "The Rank and Status of Military Refugees in the Mamluk Army: A Reconsideration of the Wāfidīyah”. Mamlūk Studies Review 10.1: 55-80.

Paul, Jürgen (2011): “Zerfall und Bestehen. Die Ǧaun-i qurban im 14. Jahrhundert”. Asiatische Studien 65.3: 695-734.

Pfeiffer, Judith (1999): “Conversion Versions: Sultan Öljeytü’s Conversion to Shi'ism (709/1309) in Muslim Narrative Sources". Mongolian Studies 22: 35-67.

Pfeiffer, Judith (2006): “Reflections on a 'Double Rapprochement:' Conversion to Islam among the Mongol Elite during the Early Ilkhanate". In: Beyond the Legacy of Genghis Khan. Edited by Linda Komaroff. Leiden: Brill, 369-389.

Qiu Yihao (2013): “Wuzu pu” yu Yilihanguo shi - “Wuzu pu” "Yilihanshixi” yizhu yu yanjiu 《五. 族譜》與伊利汗國史一《五族譜》“伊利汗世系” 譯註與研究 [SP]. Postdoctorate Research Paper, Peking University. 
Qiu Yihao (2016): “Dade er nian (1298) Yilihanguo qianshi Yuan chao kao: Faheluding Ahema Jingti de chushi ji qi Beijing, 大德二年 (1298) 伊利汗国遣使元朝考：法合鲁丁・阿合马・惕 必的出使及其背景”. Bulletin of Sinonica 87.1: 67-124.

Rashīd al-Dīn, Fazlullah (1999): Jami'u't-Tawarikh: Compendium of Chronicles: A History of Mongols, Vols. 1-3. Translated and commented by W.M. Thakston. Cambridge, MA: Harvard University, Department of Near Eastern Languages and Civilizations.

Ratchnevsky, Paul (1968): “The Levirate in the Legislation of the Yuan Dynasty”. In: Tamura hakushi shoju tōyōshi ronso. Edited by Tamura Hakushi Taikan Kinen Jigyokai. Tokyo: Dōhōsha, 45-62.

Rykin, Pavel (2013): “'Tsarevitchi’ (kö’üt) i ‘knyas’ya’ (noyat) kak basovye kategorii pravyatschey elity mongol'skoi? imperii". In: Rannie formy potestarnykh system. Edited by W.A. Popov. Saint-Petersburg: Rossiyskaya akademiya nauk, 246-266.

Satō, Tsugitaka (1997): State and Rural Society in Medieval Islam: Sultans, Muqta's, and Fallahun. Leiden: Brill.

Serruys, Henry (1957): "Remains of Mongol Customs in China during the Early Ming Period". Monumenta Serica 16.1-2: 137-190.

Smith, John Masson, Jr (1970): The History of the Sarbadār Dynasty 1336-1381 A.D. and its Sources. The Hague and Paris: Mouton.

Smith, John Masson, Jr. (1999): “Mongol Nomadism and Middle Eastern Geography: Qīshlāqs and Tümens". In: The Mongol Empire and Its Legacy. Edited by Reuven Amitai-Preiss and David O. Morgan. Leiden: Brill, 39-56.

Sneath, David (2007): The Headless State: Aristocratic Orders, Kinship Society, and the Misrepresentation of Nomadic Inner Asia. New York: Columbia University Press.

Togan, İsenbike (1998): Flexibility and Limitations in Steppe Formations. Leiden: Brill.

Vásáry, István (1990): “'History and Legend’ in Berke Khan's Conversion to Islam”. In: Aspects of Altaic Civilization, Vol. 3. Edited by Denis Sinor. Bloomington: Indiana University, Research Institute for Inner Asian Studies, 230-252.

Vásáry, István (2009): “The Jochid Realm: The Western Steppe and Eastern Europe”. In: The Cambridge History of Inner Asia. The Chinggisid Age. Edited by Nicola Di Cosmo, Allen J. Frank and Peter B. Golden. Cambridge: Cambridge University Press, 67-85.

Von Hammer-Purgstall, Joseph (1842): Geschichte der Ilchane. Darmstadt: Carl Wilhelm Leske. Wașșāf, Abdallah ibn Faḍlallah Sharaf al-Dīn Shīrāzī (2010): Geschichte Wassaf's, Vol. 1. Translated by Joseph von Hammer-Purgstall. Vienna: Verlag der Österreichischen Akademie der Wissenschaften.

Wing, Patrick (2016): The Jalayirids: Dynastic State Formation in the Mongol Middle East. Edinburgh: Edinburgh University Press.

Xie Yongmei (2012): Meng Yuan shiqi zhalayier bu yanjiu, 蒙元時期札刺亦兒部研究. Shenyang: Liaoning minzu chubanshe.

Yang, Qiao (2014): “Jiedu Yuan chao de tiankong - Semu tianwenxujia yu Yuan dai wenhua jiaolu, 解读元朝的天空-一色目天文学家与元代文化交流”. Journal of the Yuan History 14: 390-401.

Zetterstéen, K.V. (ed.) (1919): Beiträge zur Geschichte der Mamlukensultane in den Jahren 690-741 der Higra nach arabischen Hanfschriften. Leiden: Brill. 